\section{Our Bookshelf.}

An Inorganic Chemistry. By Prof. H. G. Denham. Pp. viii +684. (London : E. Arnold and Co., r922.) I2s. $6 d$. net.

Prof. Denham has written "An Inorganic Chemistry" for intermediate students. In this field at least half-adozen excellent text-books are already available ; but, perhaps for commercial reasons, additional volumes of similar scope continue to be produced, and the process may be expected to continue until each leading publisher is able to offer a book of this type. Prof. Denham's book is well printed and nicely illustrated, and in this respect compares favourably with other competing volumes.

The author claims as a simplifying factor the introduction of the periodic classification of the elements in the middle (instead of at the end) of the chapters on the non-metals; but it is doubtful whether this policy will be followed by other authors, because it is obviously difficult to classify the elements when only two groups of them have been described. The policy of including a brief description of all the less common elements (except those of the "rare earths ") is also of doubtful value, in view of the great difficulty which intermediate students find in becoming acquainted even with the common elements when they pass from the study of the non-metals to that of the metals. More important perhaps is the fact that while atomic weights are given at a very early stage, Avogadro's hypothesis and the molecular theory are postponed to Chapter IX., with the result that for nearly Ioo pages hydrogen gas is represented as $\mathrm{H}$ and oxygen gas as $\mathrm{O}$; in the meantime, subjects such as the theory of solutions and thermo-chemistry, and even valency and structural formulæ, are discussed on this very inadequate basis.

The author's attention may be directed to the incorrect statements which result from his undue simplification of crystal forms, which he classifies by means of planes of symmetry instead of by means of crystallographic axes. It would also be well if it were clearly stated that the vapour-pressure curves of the different forms of sulphur are purely fictitious, although they are presented in the same attractive form as the solubility diagrams, which are a pleasing feature of the book; it may be suggested that the omission of the small squares might be used to distinguish those diagrams which are mere sketches from those where accurate data are given.

T. M. L.

Happy India as it Might Be if Guided by Modern Science. By A. Lupton. Pp. I88. (London: G. Allen and Unwin, Ltd., I922.) 6s. net.

Mr. Lupton in a single cold-weather tour through the Indian Empire has tried to solve a series of economic problems, which have long engaged the attention of administrators and men of science. He is impressed, as all thoughtful observers of Indian life must be, with the general poverty of the people, their exhaustion by malaria, and their inability to resist periodical scarcity. The soil is ineffectually cultivated by weak plough cattle, the produce is extremely low when compared with that of other more fortunate countries, and much of the scanty manure is used as fuel. Here is the chance of science. Why not have a chemical examina- tion of the soils of each district to find out what constituents are lacking? Why not establish a fuel reserve in each village? Why not lay down at every peasant's door wood from the Himalayas or coal from Bengal? Why not use electricity to pump water from the wells? Why not fill every puddle and so abolish malaria?

These are admirable schemes, but unfortunately the Government does not possess the means of raising enormous loans, paying the interest, or maintaining a new army of officials, in the hope that some day it will be repaid for the cost of $7,000,000$ tons of superphosphates which he proposes to import, even if such a demand did not upset agriculture all the world over. It is very well to say, spend a few millions as a beginning, but this would do little to improve the situation, and, as he admits, there is little use in giving ignorant people superphosphates if you do not at the same time supervise their use by a corpus of experts. Even to make a fuel reserve in a village means taking up arable land for this purpose, and the peasant does not like reserves because they shelter wild pig, monkeys, and green parrots, his greatest enemies.

Mr. Lupton honestly admits that the Government is not to be blamed because every. Hindu marries and rears a family, resulting in congestion of the population. He hopes vaguely that public opinion will check this abuse, but he admits that the educated Indian gentleman knows or cares little about the peasantry, and that " if the Indians govern themselves, we may be sure that their government will be bad." Mr. Lupton is to be commended for his good intentions, his fine sense of humanity, but it needs practical wisdom to consider the problems which he has attempted to solve.

The West Riding of Yorkshire. By Bernard Hobson.

Pp. xii + r88. (Cambridge: At the University Press, I921.) 3s. 6 d. net.

Mr. Bernard Hobson had a difficult task to describe the West Riding of Yorkshire owing to the wealth of the material. The term "Riding" means onethird, so that the area dealt with is only one-third of the county of Yorkshire; but as it includes the densely populated coalfield to the south and the limestone moors to the north-west, it contains areas of special importance and interest. Mr. Hobson has not only: compiled an instructive summary of the geography, geology, and history of the West Riding, but has also presented it in a form interesting throughout. The most important geographical feature of the area is the Pennine Range, forming its western highlands, which is unique in England from the extent of its subterranean river system. The industrial districts include many important cities ; the author's account of Sheffield is of especial interest. The history of man in the area dates from Neolithic times, for Mr. Hobson tells us that no undoubted trace of Palæolithic man has yet been found, though abundant remains occur only three miles from the Yorkshire border. The area is especially rich in archæological and historical monuments. In the chapter on the architecture it is remarked that the professional architect arose in the period of James I., before which building had been in the hands of the builder and the craftsman. Apparently, therefore, the end of the great age of building in England synchronises with the rise of the professional architect. 